\title{
User Involvement: Effective Performance in Sustainable Social Housing
}

Jan Johansson

Denmark

\begin{abstract}
In the development of sustainable social housing, the residents, operating staff, and administrative staff - as users - face challenges in relation to a lack of involvement. The aim of this research is to contribute with results regarding these challenges. These contributions to the discussion are based on the results of a qualitative evaluation of sustainable social housing. The results suggest that it can be an advantage to utilise user experiences in the development of future sustainable social housing with a view to strengthening the user involvement process. The argument is that a greater degree of user involvement respects people's experiences as being a contribution to the development of new projects. In addition, the research suggests that the early involvement of residents, operating staff, and administrative staff can strengthen the sense of project ownership and community, as well as the project's social sustainability. It is claimed that user involvement can promote social sustainability, which is a significant factor, since the intention behind a project's sustainability is that the residents will later have ownership and an interest in ensuring that it works in accordance with its intentions.
\end{abstract}

Keywords: architecture, building performance, green buildings, post-occ. evaluation, sustainability.

\section{Introduction}

User involvement is an absolutely fundamental part of the Danish social sector like the housing movement, and all Danish social housing organisations are managed by resident democracy. Resident democracy is included in legislation that gives the residents the right to make decisions about their own housing and the housing area. The residents have majority rights, partly on the board of the housing organisation's executive committee and management board, but also at the other democratic residential levels such as the department committee, building committee, etc. (Rogaczewska et al., 2014). 
Resident democracy distinguishes itself by being closely interwoven with everyday life's social contexts and to a great extent by living by these contexts. Regulation, or stimulation, of the democratic resident activities must therefore take into account the social element; that there are people who are looking for, need, or value spending time together and who practice political housing activity (Jensen et al., 1999).

When something has to be built or renovated in a social housing development, the resident democracy establishes a building committee - typically with representatives from the department's executive committee, building administration, as well as architects, engineers, etc. During the entire project, the building committee thus represents one or more representatives. During the process, the administrative or operating staff can equally be included with their knowledge.

Via the building committee, the resident democracy is thus involved in the entire process, from the building programme, planning, execution, and all the way through to the building's operation. The building committee participates in regular building meetings, and the resident representatives continuously approve the project's finances and content. The housing association's project manager, building administration, and operating administration thus have a particular knowledge about the future servicing of the users in the operating phase, as well as knowledge about how the residents' behaviour will ensure optimal use of the homes in the operating phase.

In general, the Danish social housing sector has considerable expertise and better conditions for carrying out sustainability goals in the running of their buildings in relation to other forms of ownership (privately owned and privately rented). There is strong engagement in sustainability issues amongst administrators, who have experience in relation to being entrepreneurs for both many and large units. The weaknesses are that the residents' ownership of the building is often small and often has a short time frame in relation to long-term investments, which is a requirement for sustainable construction (Nielsen et al., 2012).

Sustainable architecture should be simple, since it is so-called "ordinary people" who will live in it (Bordass and Leaman 2013), because they want to live as "ordinary" a life as possible without being particularly interested in the environment or showing particular interest in sustainable ways of living (Jensen et al., 2012). The users' consumption and behaviour (Shove 2003) - and hence lacking or unintended consequences of this in relation to the intentions - must not be used as an excuse by the architects and other experts when sustainable construction does not work. The users' behaviour must be understood and influenced in a respectful way. If longlasting sustainable solutions are to be met, then architectural practice must approach the task with a humble, respectful approach to the users (Bordass and Leaman 2013).

Complex requirements are placed on architectural practice, with a comprehensive understanding of all aspects of sustainability. In this regard, architectural practice 
must be able to professionally engage in a broad range of disciplines and specialities. At the same time, design requirements are also made in relation to the users' role (Bordass et al., 1994) and that the users' role gives rise to requirements for the building's operation (Leaman and Bordass 1993)(Leaman and Bordass 1997). Architectural practice should therefore direct its focus towards the users' role and requirements for the building's operation in order to be able to achieve intentions for sustainability's so-called "triple bottom line" (Twinn 2012).

Construction Management, Users, and Qualitative Evaluation

More knowledge about the interaction between residents, administrative staff, and operating staff is valuable for those developing new housing as well as its subsequent operation (Leaman et al., 2010). We should focus on the building as it is used so that the experiences can be utilised in the design process of future constructions (Stevenson and Leaman 2010), where residents are often the best judges of buildings and can contribute with valuable feedback (Grierson and Moultrie 2011).

In this connection, this paper would like to contribute to the discussion of the area of construction management with results as well as in relation to the challenges of a lack of user involvement in relation to the intentions regarding the performance of sustainable social housing.

\section{Methodology}

\section{Research Question}

The guiding research question was: Does the sustainability in sustainable social housing work for residents, operating staff, and administrative staff? And this also included the sub-questions: What are the users' experiences of sustainable social housing? How can the users' experiences be used in the development of future sustainable social housing?

\section{Theoretical aspects}

In using a phenomenological approach, the project's study design has taken its starting point in the early Husserl's epistemological preoccupation of investigating people's realisation and describing their experiences of the phenomena (Zahavi 2006). The task has been to go "to the issue itself" without preconceived opinions and theories (Rendtorff 2003). There is no objective, independent research object but in contrast a subjective experience and the attribution of meaning in particular life worlds (Justesen and Mik-Meyer 2010).

In principal, phenomenology was chosen in order to have an open and unbiased opportunity to capture people's life worlds. At the same time, this approach has an impact on the methodological research method, where the use of the interview as a method (Kvale and Brinkmann 2015) can contribute to the issue with many spontaneous, rich, and specific answers, as well as an ideal of achieving "thick 
descriptions" (Geertz 1973).

\section{Criteria for Case Selection}

The study is limited to including three family-friendly and sustainable terraced social housing buildings in Denmark. The buildings are experimental constructions that have neither been renovated nor rebuilt after being taken into use. The choice of buildings that have not been renovated and/or rebuilt after being taken into use is because the aim is to capture the users' experiences with buildings that have been taken into use over a longer period in relation to the original intentions regarding sustainability. The choice of multiple cases is made in order to strengthen the precision, validity, and stability of the results (Neergaard 2010).

The three case studies are chosen based on the criteria of maximum variation. By choosing a small number of cases with maximum variation, the data gathering and data analysis will give two kinds of result. Firstly, it provides detailed descriptions that can document unique features in the individual cases. Secondly, it can identify important common patterns across the cases, which has vital importance (significance), because they occur on the basis of heterogeneity (Neergaard 2010).

With reference to "documenting unique features" in the three cases, the following criteria are chosen: Case 1: "Økohus 99" - sustainability: low-energy construction (little) with ecological initiatives; Case 2: "Lærkehaven III" - sustainability: lowenergy construction (a lot) according to the Passive House standard; Case 3: "Grøndalsvænge" - sustainability: low-energy construction (medium) sustainable building operation with increased self-management.

\section{Methods}

For each of the three case studies, the following three combinations of methods are used: semi-structured deep interviews (method 1), semi-structured focus group interviews (method 2), and structured deep interviews (method 3). In this way, the strength of validity was sought with the help of three subsequent follow-up methods as the basis for a triangulation of methods (Barbour 2007). Seventeen semistructured deep interviews, three semi-structured focus group interviews, and six structured deep interviews were carried out.

In method 1, the residents (snowball sampling), operating staff (key people), and staff from the operating administration (key people) were interviewed individually using semi-structured deep interviews. The essences of phenomenological analysis (Tanggaard and Brinkmann 2010) have been used to formulate the questionnaire for method 2 .

In method 2, the same users were invited to participate in semi-structured focus group interviews (Barbour 2007). The essences from the phenomenological analyses from method 1 and method 2 were used as the questionnaire when carrying out 
method 3. The coupling of identical results from method 1 and 2 contributed to a further strengthening of validity and potential generalisability in relation to typical features (Giorgi and Giorgi 2003). The qualitative focus group interview is chosen in order to be able to see patterns and general processes, categories, and dynamics in the user groups. It is based on these elements that generalisations can be made (Halkier 2008). The criterion about communicative validation (Kvale and Brinkmann 2015) was furthermore brought into play in method 2 , since parts of results from the analysis are presented to the interviewees, who have contributed to the empirical material and in that way are a part of validating the analysis' results.

In method 3, both the developers (key people) and the architects (key people) were interviewed individually using structured deep interviews (Justesen and Mik-Meyer 2010) with a view to whether the users' experiences could be used in the development of future sustainable social housing. The essences from the phenomenological analyses (methods 1 and 2) give rise to new questions to be used in preparing the interview guide and carrying out method 3.

\section{Case studies}

\section{Case 1: “Økohus 99"}

The "Økohus 99" settlement was finished in 1998 and is located in the town of Ikast, $67 \mathrm{~km}$ west of Aarhus, Denmark. The buildings are the result of an architecture competition for the construction of what could be called first-generation, low-energy terraced houses with ecological initiatives. The terraced houses are designed by Tegnestuen Vandkunsten and are run by the housing organisation Bomidtvest.

Typical sustainable characteristics are the zoned house, exploiting the passive heat from the sun in the "Sunhouse". In addition, the buildings have ecological initiatives in the outside areas in the form of a lake collecting rainwater with a root zone system and water channels. The water channels are an integrated part of the homes' cooling system. In order for the intentions behind the architecture to work, a high degree of user involvement is required.

Ecology as a principal goes back to the beginning of the 1970s, where the grassroots environmental groups tried to transform a sustainable way of thinking into an architectural mode of expression. The grassroots groups' structural answer has been based on environmental sustainability with an ecological basis. The ecological construction attached importance to the incorporation of "natural" building materials, reusable materials, and alternative building forms. The architects chose to build according to traditional building methods, with the use of so-called "clean" building materials based on simple production.

\section{Case 2: "Lærkehaven III"}

The "Lærkehaven III" settlement was finished in 2010 and is located in the town of 
Lystrup, 14 km north of Aarhus, and is run by the housing organisation Ringgården. The buildings are designed by Schmidt Hammer Lassen Architects and are the result of an international project competition, with the goal of being able to display sustainable residential architecture according to the Passive House standard. The buildings have green common areas and a lake that collects rainwater, with adjoining water channels as additional environmental, sustainable initiatives. Its function is to counteract flooding and unnecessary loads on the sewer system. The buildings were built by a German contractor.

The Passive House standard goes back to the 1990s, where architects from, amongst other countries, Germany and Austria experimented with refining the low-energy house by optimising the technologies' and the constructions' energy efficiency in order to achieve environmental sustainability. Typical sustainable characteristics are the highly insulated, low-energy house and represent the first larger terraced social housing in Denmark in accordance with the principals of the Passive House standard. The requirements are that the houses, without help from renewable energy sources, are allowed to use a maximum of $15 \mathrm{kWh} / \mathrm{m}^{2}$ per year on heating and cooling. In addition, there is a requirement regarding the building's airtightness, which is not allowed to be greater than $0.6 \mathrm{~m}^{3} / \mathrm{h} / \mathrm{m}^{3}$.

\section{Case 3: "Grøndalsvænge"}

The "Grøndalsvænge" settlement was finished in 2012 and is located in Copenhagen. It is run by the housing organisation KAB. The buildings are designed by ONV architects and are the result of one of many experimental constructions built according to a concept that mainly combines reducing the cost of production with the residents' increased self-management in running the building.

Typical sustainable characteristics are the highly insulated, low-energy house built according to energy class 2020. The buildings are built with mechanical ventilation with heat recovery. In addition, the residents' "do-it-yourself" involvement in the home's flexible layout, operation, and maintenance, as well as the building's operation are a representation of social sustainability.

\section{Discussion}

The results of the study show a lack of involvement of residents, operating staff, and administrative staff when sustainable social housing is planned and ideas are developed. The three user groups would like to be involved early on so that they can contribute with their operating experiences as well as ideas, dreams, and wishes for the good home life. The assumption that user involvement should, for example, first take place after the winner of an architecture competition has been chosen does not fit with the users' perception of what the concept user involvement means. The absence of involvement is therefore experienced as insufficient and appears as a dimension of social sustainability that has not worked for the users. 
Why should the users be involved? On the one hand, it would be quicker, easier, and cheaper for a developer not to involve the users. The argument could be made that the developer and the housing organisation could start building the project faster and at the same time save time and money. By choosing not to involve users, the developer and the housing organisation could avoid the "difficulty" of a large number of meetings, workshops, moderators, follow-up meetings, etc. in order to save time and money to the benefit of the project.

However, an alternative argument is that user involvement is essentially about having respect for other people's right to co-determination. In addition, it can be claimed that user involvement would contribute to the sense of ownership of the project amongst the users, which means that they take on a shared responsibility for the decisions that are made. The users therefore have to be responsible for both the good as well as the not-so-good decisions for, for example, the residents when the development reaches the operating phase. The users' joint responsibility can at the same time alleviate the burden of responsibility from the developers' and advisors' shoulders when the intentions behind the sustainability do not function as required.

The author believes that if one adopts the Brundtland Report's three-pillar model of the concept of sustainability, then there should be an equal weighting of environmental sustainability, social sustainability, and economic sustainability (Jensen et al., 2014), in which user involvement as social sustainability, also applies at the local housing level when new sustainable social housing is developed.

In addition, the author also believes that the developers ought to respect and accept the necessity of user-involving processes with the participation of the operating staff, administrative staff, and the residents, in spite of the argument about a lack of time. After all, the goal must be to build sustainable social housing that works for the users and benefits sustainability.

In relation to the residents' "voice", it will have been represented through either the local council committee, management board's resident representatives, or by the executive committee's resident representation. It is argued that it is not sufficient to simply involve the selected committee members if they have not had experience of living in sustainable housing. Therefore, it is suggested that the residents should be more widely represented, where residents who have lived in sustainable social housing and their experiences can be used to benefit the development of future sustainable social housing. A wider representation of users can, in the long term, contribute to the project ownership and the motivation amongst the users to get the sustainability in the finished sustainable social housing development to work.

On the one hand, it is not possible to unequivocally claim that the "users' voice" has not been represented in the development process, since the residents are - through the resident democracy - represented via a management board or executive committee. Furthermore, it can be claimed that the local council committee, as 
representatives for the residents of Ikast council, thus represents the "residents' voices" when new social housing is developed.

On the other hand, it can be claimed that the decision-making processes have become too distant in relation to the real users and their ideas, dreams, and desire for the good home life.

According to the secretariat employee from the City and Housing Ministry in Case 1, an extended dialogue has been introduced, which means that the councils now have a certain responsibility for having a dialogue with their local housing organisations.

It is argued that it is not enough that future residents are only represented via a management board, executive committee, or council committee. There should be a focus on the three groups becoming involved in the collaboration with the council and housing organisation earlier so that they can contribute with their operating experiences as well as ideas, dreams, and wishes for the good home life. The author believes that if society is to move in a more sustainable direction, then this will happen by taking a starting point in the local activities at the residential level.

The results show that a broader representation of users that are included during the development process can, in the long term, contribute to the project ownership and the motivation amongst the users. Project ownership and motivation will be fundamental conditions for getting the sustainability in the finished sustainable social housing development to work.

When is it relevant to include the users? On the one hand, it is possible to say that it is only relevant to include the operating staff and administrative staff early in the process. Here, it would be possible to take advantage of their operational experiences when new sustainable housing projects are developed. One could refrain from including the residents in the process, since it is in any case not known which residents will move in. On the other hand, it cannot be expected that the operating staff, administrative staff, and the developer know the ideas, dreams, and wishes for the good home life. Ideas, dreams, and wishes are best introduced in the planning phase if they are to be relevant to the residents.

Why should user involvement occur? On the one hand, it is possible to imagine that user involvement, with the holding of meetings locally in Ikast, could support the administrative staff in feeling "seen and heard". It is presumed that this signals a seriousness towards the users if "them" from Copenhagen went "all the way" to Ikast. That "them from the capital city" were willing to "sacrifice" the time it takes to go "all the way" over to "them in the provinces". Accommodating the users on this point can support their project ownership and motivation. But on the other hand, it would mean that the business-driving housing association, for example in Case 1, would have to travel "all the way" to Ikast when they were to meet. The distance between Copenhagen and Ikast undoubtedly also constitutes a barrier in itself due to the long 
travelling time.

It is crucial to understand how resident democracy works in order to be able to carry out initiatives aimed at a local, sustainable readjustment. There are examples of the management and the administration wanting to carry out a range of changes or improvements that have still not been realised, since there has not been a sufficient awareness of how it is the residents who decide at the end of the day (Jensen et al., 2008).

In addition, AlmenNet has published a guideline in relation to user involvement in all phases of the development. The publication defines the introductory part of the development's phase as "involvement in the drawing and calculating phase". In this phase, it is emphasised that: "one must be very aware of creating good conditions for collaboration and the collective feeling of responsibility for the project... One therefore easily risks that the active residents become - or feel - misunderstood. Just like the intentions and values that have been behind the project from the beginning are forgotten" (AlmenNet 2008).

The author believes that there is, on the other hand, a paradox in that the branch organisation AlmenNet, on behalf of the social housing organisations in Denmark, emphasises the importance of early user involvement when this is not practiced in reality.

At the same time, there is the distinction that a wider representation of users can, in the long run, contribute to the project ownership and motivation amongst the users in order to get the sustainability in the finished sustainable social housing development to work. The author believes that a greater degree of user involvement respects other people's experiences as being a contribution to the development of new projects. Thus, a broader overall consideration could be applied in relation to what sustainability is about, with reference to the three-pillar sustainability model. The point is that social sustainability is just as important a parameter in sustainable social housing as economic and environmental sustainability.

By including the three user groups, it is also possible to minimise the creation of myths, negative narratives, promote communication, as well as increase knowledge and information. Because what is the point of skipping user involvement if the users subsequently feel overlooked and it reduces the sense of ownership of the project? Where is the enjoyment in building sustainable social housing if it does not work for the users or benefit the sustainability?

\section{Conclusion}

To conclude, there appears to be a pattern across the three cases of a lack of the involvement of residents, operating staff, and administrative staff when sustainable social housing is planned and ideas are developed. In relation to the resident's "voice", it has only been represented through the local council committee, management 
board's resident representatives, or by the executive committee's resident representation. The lacking user involvement shows important common patterns across the cases and can have critical importance (significance), because they occur on the basis of heterogeneity.

It is suggested that it can be beneficial to make use of user experiences in the development of future sustainable social housing with a view to strengthening the user-involvement process. The argument is that a greater degree of user involvement respects other people's experiences as being a contribution to the development of new projects. Furthermore, the early involvement of users can strengthen project ownership, community, as well as social sustainability.

The initiative takers, developers, and business-leading companies should have a special attention towards involving all the users via, for instance, a "user panel". An early involvement of users must in this way make use of the operating and administrative staff's experiences as well as respect the residents' ideas, dreams, and wishes for their homes.

It would therefore be appropriate that residents, operating staff, and administrative staff are involved throughout all of the project's development and decision-making processes - also with representation from future residents. This means that the three user groups should prospectively have, amongst other things, a real influence on the written text in the planning phase, which forms the basis for the subsequent architecture competition; involvement in the idea phase, which can influence the architecture; involvement in the contracting phase; where the economic decisions are made, amongst others; involvement in the initialisation phase with the handing over of knowledge and information; as well as involvement in the operating phase, with the continuous exchange of experiences.

It is claimed that this user involvement can promote social sustainability, which is a significant factor when considering that the intention behind a building project's sustainability must subsequently have the residents', operating staff's, and administrative staff's interest in ensuring that it functions in the operating phase.

Furthermore, it is argued that user involvement, as an element in the three-pillar model, inserts itself as social sustainability. The point is that social sustainability is just as important a parameter in sustainable social housing as economic and environmental sustainability. Through a greater focus on user involvement, a broader overall consideration is thus applied with its starting point in a discourse, where social sustainability supports an effective performance in sustainable social housing.

\section{References}

[1] AlmenNet (2008) AlmenVejledning C3: Beboerdemokratisk proces 02 - Fra skema A til skema $C$ [Common Guidance C3: The resident democratic process 02 - from plan A to plan C]. Copenhagen: AlmenNet 
[2] Barbour, R (2007) Doing focus groups. The SAGE Qualitative Research Kit. Thousand Oaks, CA: Sage Publications.

[3] Bordass, B and Leaman, A (2013) Part 2: Building Performance: The Bigger Picture. Building professionals and the challenge of sustainability, https://www.youtube.com/watch?v=92L0IDGWi3U [Accessed on 29 March 2019].

[4] Bordass, B, Leaman A and Willis, S (1994) Control Strategies for Building Services: the role of the user In: Proceedings of the BRE/CIB Conference on Buildings and the Environment, 16-20 May 1994, UK.

[5] Geertz, C (1973) The Interpretation of Cultures: Selected Essays. New York: Basic Books.

[6] Giorgi, A and Giorgi, B (2003) The Descriptive Phenomenological Psychological Method. In: Camic, P M (Ed.) Qualitative Research in Psychology - Expanding perspectives in methodology and design, 243-273. Washington DC: American Psychological Association.

[7] Grierson, D and Moultrie, C (2011) Architectural Design Principles and Processes for Sustainability: Towards a Typology of Sustainable Building Design. Design Principles and Practices: An International Journal, 5(4), 623634.

[8] Halkier, B (2008) Fokusgrupper [Focus groups]. Frederiksberg: Samfundslitteratur.

[9] Jensen, J O, Jensen P A, Elle M, Hoffmann B, Nielsen, S B and Quitzau, M-B (2008) Miljøstyret bygningsdrift i danske boligejendomme: under forskellige ejerformer [Environment-managed building operation in Danish housing properties: Under different types of ownership]. Hørsholm: Statens Byggeforskningsinstitut.

[10] Jensen, J O, Jensen, O M and Gram-Hanssen, G (2014) Omstilling til bæredygtigt byggeri [Transition to sustainable construction]. In: Holm, J, Søndergård, B, Stauning, I and Jensen, J O (Eds.), Bæredygtigt omstilling af bolig og byggeri [Sustainable transition of housing and construction], 73-106. Frederiksberg: Frydenlund Academic.

[11] Jensen, J O, Jørgensen, M S, Elle, M and Lauridsen, E H (2012) Has social sustainability left the building? The recent conceptualisation of 'sustainability' in Danish buildings. Sustainability: Science, Practice and Policy, 8(1), 94-105.

[12] Jensen, L, Kirkegaard, O and Pedersen, D O (1999) Beboerdemokrati og forvaltning i den almene boligsektor. Idealer og praksis [Resident democracy and administration in the social housing sector]. Vol. 322. Hørsholm: Statens Byggeforskningsinstitut.

[13] Justesen, L and Mik-Meyer, N (2010) Kvalitative metoder [Qualitative methods]. Copenhagen: Hans Reitzels Forlag.

[14] Kvale, S and Brinkmann, S (2015) Interview: Det kvalitative 
forskningsinterview som håndværk [Interview: The qualitative research interview as craft]. 3. ed. Copenhagen: Hans Reitzel Forlag.

[15] Leaman, A and Bordass, B (1993) Building Design, Complexity and Manageability. Facilities, 11(9), 16-27.

[16] Leaman, A and Bordass, B (1997) Strategies for Better Occupant Satisfaction. In: Proceedings of the $5^{\text {th }}$ Indoor Air Quality Conference, 10 July 1997, British Library, London.

[17] Leaman, A, Stevenson, F and Bordass, B (2010) Building evaluation: practice and principles. Building Research and Information, 38(5), 564-77.

[18] Neergaard, H (2010) Udvælgelse af cases $i$ kvalitative undersøgelser [Selection of cases in qualitative studies]. Frederiksberg: Samfundslitteratur.

[19] Nielsen, S B, Jensen, P A and Jensen, J O (2012) The strategic facilities management organisation in housing: Implication for sustainable facilities management. International Journal of Facility Management, 3(1), 1-15.

[20] Rendtorff, J D (2003) Fænomenologien og dens betydning [Phenomenology and its importance]. In: Fuglsang, L and Olsen, P B (Eds.), Videnskabsteori $i$ samfundsvidenskaberne: på tværs af fagkulturer og paradigmer [Theory of science in the social sciences: Across subject cultures and paradigms], 133167. Frederiksberg: Roskilde Universitetsforlag.

[21] Rogaczewska, N A, Lønne, R and Sørensen, K F (Eds.)(2014) At huse alle [How to House]. Århus: BL-Danmarks Almene Boliger.

[22] Shove, E (2003) Comfort, Cleanliness and Convenience - The Social Organization of Normality. Oxford, England; New York: Berg

[23] Stevenson, F and Leaman, A (2010) Evaluation housing performance in relation to human behavior: new challenges. Building Research and Information, 38(5), 437-441.

[24] Tanggaard, L and Brinkmann, S (2010) Interviewet: Samtalen som forskningsmetode [Interview: The interview as a research method]. In: Brinkmann, S and Tanggaard, L (Eds.) Kvalitative metoder - en grundbog [Qualitative methods - a basic book], 2. ed., 29-53. Copenhagen: Hans Reitzels Forlag.

[25] Twinn, C (2012) Professionalism, sustainability and the public interest: what next?, Building Research and Information, 41(1), 123-28.

[26] Zahavi, D (2006) Edmund Husserl - Hvordan verden træder frem [Edmund Husserl - How the world emerges]. In: Thau, C (Ed.), Filosofi and arkitektur $i$ det 20. Arhundrede [Philosophy and architecture in the $20^{\text {th }}$ century], 7-18. Copenhagen: Kunstakademiets Arkitektskole. 